\title{
Effect of Different Packaging Materials and Pre-Storage Treatments on Storability of Chickpea (Cicer arietinum L.) Seeds
}

\author{
Jagnnath Gupta*, Abhinav Dayal, A.K. Chaurasia, Vishal Kumar and Nawaz Ali \\ Department of Genetics and Plant Breeding, Sam Higginbottom University of Agriculture, \\ Technology \& Sciences, Allahabad-211007, U.P. (India) \\ *Corresponding author
}

\begin{abstract}
A B S T R A C T
\section{Keywords}

Chickpea, Variety, treatment,

Packaging materials, Storage and seed quality

Article Info

Accepted:

12 July 2018

Available Online:

10 August 2018

The present investigation a series of laboratory experimental was conducted in the post graduate Seed Testing Laboratory, Department of Genetics and plant Breeding, Sam Higginbottom University of Agriculture, Technology \& sciences Allahabad, Uttar Pradesh, India during 2017-2018. Chickpea variety (C- 128) and (C-130) was obtained from department of Genetic and plant breeding Research farm at SHUATS Allahabad UP. Seed treated Camphor oil @10 ml/kg seed (T1), Castor oil @ 5 ml/kg seed (T2), Neem oil @ $10 \mathrm{ml} / \mathrm{kg}$ seed (T3), Eucalyptus oil @ $10 \mathrm{ml} / \mathrm{kg}$ (T4) seed alone with control (untreated T0) and packed in polythene bag (P1), air tight box (P2), cloth bag (P3) and paper bag (P4) and maintained for 6 months with $8 \%$ seed moisture content under ambient conditions. The result clearly revealed that seed stored in polythene bag and treated with neem oil, variety C-130 (V2) was found high germination per cent (84.83\%) and lowest electrical conductivity $\left(1.54 \mathrm{dsm}^{-1}\right)$ was recorded variety C-130 (V2) and other parameters like root length $(14.83 \mathrm{~cm})$, shoot length $(11.19 \mathrm{~cm})$, seedling length $(26.00 \mathrm{~cm})$, fresh weight (3.40g), dry weight (1.27g), vigour index-I (1969) and vigour index- II (94.24) were found best in variety C-128 (V1) found superior than variety C-130 (V2).
\end{abstract}

\section{Introduction}

Chickpea (Cicer arietinum L.) is commonly known as Bengal gram, gram, Chana, kadle etc. and is the third most important pulse crop in the world after beans and peas. Turkey was the area where chickpea was believed to be originated (Ven der Maesen, 1984).

Chickpea is popularly cultivated in subtropical and semi-arid to warm temperate regions under dry season. Chickpea is predominantly consumed in the form of whole grain dhal, sprouted grain, green or matured dry seed and is used in the preparation of variety of snacks, sweets and condiments. It has highly digestible protein (21.1\%), carbohydrate (61.5\%) and fat (4.5\%), relatively free from anti nutritional factors and is rich in phosphorus, iron, niacin and calcium compared to other pulses. Its tender leaves are used as vegetable while, its acid exudates 
(mainly oxalic and malic acid) as a popular refreshing drink and medicinally for blood purification (Bahl and Salimath, 1996).

India is one of the chickpea growing countries in Asia with an area 9.539 million hectares and production of 9.75 million tones with an average productivity of $951 \mathrm{~kg}$ per hectare (DES, 2016-2017)

Losses in seed quality occur during field weathering, harvesting and storage due to which seeds get damaged. If seeds are exposed to high temperature and high humidity, the incidence of microflora is mainly responsible for the degradation of protein and other food reserve resulting in reduction in viability, vigour and germination. Packaging materials play a major role in prolonging the safe life of seed during storage as they separate seeds from the surrounding environment. Some packaging materials are moisture pervious and some are impervious, suitability of various packaging materials for safe storage of seeds for longer periods seeds to be studied various crop seeds especially the poor stores like chickpea. Being hygroscopic in nature, the viability and vigour of seeds under storage are known to be regulated by variation in the physio-chemical factors, initial seed quality and packaging material (Doijode, 1988).

\section{Materials and Methods}

The experiment was laid down in a Factorial complete randomized design (FCRD) with three replications. The chickpea seed $\mathrm{C}-128$ (V1) and C-130 (V2) were sun dried to a uniform moisture content of $8 \%$ before proceeding for storage. Seed was treated with camphor oil $10 \mathrm{ml} / \mathrm{kg}$ seed $\left(\mathrm{T}_{1}\right)$, castor oil $5 \mathrm{ml} / \mathrm{kg}$ seed $\left(\mathrm{T}_{2}\right)$, neem oil $10 \mathrm{ml} / \mathrm{kg}$ seed $\left(\mathrm{T}_{3}\right)$ and eucalyptus oil $10 \mathrm{ml} / \mathrm{kg}$ seed $\left(\mathrm{T}_{4}\right)$ with local control $\left(\mathrm{T}_{0}\right)$ stored for three (6) months at ambient room temperature in the post graduate Seed Testing Laboratory of Department of Genetics and Plant Breeding,
Naini Agricultural Institute, SHUATS, Allahabad, with packed in four packaging materials viz (Polythene bag, Air tight box, Cloth bag and Pepper bag)

\section{Results and Discussion}

\section{Germination percent}

A significant effect on germination percent was observed by using different seed treatment throughout the storage periods (Table 1). The results revealed that seed treatment with neem oil recorded higher germination percentageV1 $(81.58 \%)$ and V2 $(91.67 \%)$ after 6 months of storage periods, respectively. The seed germination percent was found high germination percent in V2 $(84.83 \%)$ than V1 $(75.32 \%)$ after 6 months of storage. With packaging materials polythene bag in packed seeds found significantly higher germination percent V1 $(82.47 \%)$ and V2 $(90.67 \%)$ after 6 months of storage periods, respectively. Similar results were reported by Singh et al., (2007) also observed highly effect and difference for treatments, containers and storage period for germination percentage.

\section{Root length}

The effect of seed treatments on root length (cm) was significant after 6 months of storage periods (Table 1). Results revealed that significantly highest root length V1 (16.25 $\mathrm{cm})$ and V2 $(12.09 \mathrm{~cm})$ was recordedseeds treated with neem oil treatment after 6 months of storage periods, respectively. The highest root length was found in $(\mathrm{C}-128,14.83 \mathrm{~cm})$ than $(\mathrm{C}-130,11.45 \mathrm{~cm})$ after 6 months of storage. With packaging materialspolythene bagin packed seeds V1 and V2 found significantly highest root length after 6 months of storage. Treated of seeds with bioagent have protected the seed from influence of above factors resulting in maintenance of seed quality for a comparatively longer period. 


\section{Shoot length}

The effect of seed treatments on root length (cm) was significant after 6 months of storage periods (Table 1). Results revealed that significantly highest shoot length V1 (11.19 $\mathrm{cm})$ and V2 $(11.06 \mathrm{~cm})$ was recorded seeds treated with neem oil treatment after 6 months of storage periods, respectively. The highest shoot length was found in $(\mathrm{C}-128,11.19 \mathrm{~cm})$ than $(\mathrm{C}-130,11.06 \mathrm{~cm})$ after 6 months of storage. With packaging materials polythene bag in packed seeds V1 and V2 found significantly highest shoot length after 6 months of storage.

Increase in shoot length may be due to decline in seedling length at the end of the storage period might be attributed to age induced decline in seed germination as well as damage caused by fungi and toxic metabolites which might have hindered the shoot growth.

\section{Seedling length}

The effect of seed treatments on seedling length $(\mathrm{cm})$ was significant after 6 months of storage periods (Table 2). Results revealed that significantly highest seedling length V1 $(27.71 \mathrm{~cm})$ and $V 2(23.74 \mathrm{~cm})$ was recorded seeds treated with neem oil treatment after 6 months of storage periods, respectively. The highest seedling length was found in (C-128, $26.00 \mathrm{~cm})$ than $(\mathrm{C}-130,22.51 \mathrm{~cm})$ after 6 months of storage. With packaging materials polythene bag in packed seeds V1 and V2 found significantly highest shoot length after 6 months of storage.

\section{Seedling fresh weight}

The effect of seed treatments on seedling fresh weight $(\mathrm{g})$ was significant after 6 months of storage periods (Table 2). Results revealed that significantly highest seedling fresh weight $(3.55$ and $3.60 \mathrm{~g}$ ) was found seeds treated with neem oil treatment after 6 months of storage periods, respectively. The highest seedling fresh weight was found in (C-130, $3.40 \mathrm{~g})$ than $(\mathrm{C}-128,3.39 \mathrm{~g})$ after 6 months of storage. With packaging materials p0lythene bag in packed seeds found highest fresh weight V1 and whereas packaging materials air tight box in packed seed highest fresh weight V2 after 6 months of storage.

\section{Seedling dry weight}

The effect of seed treatments on seedling dry weight $(\mathrm{g})$ was significant after 6 months of storage periods (Table 2). Results revealed that significantly highest seedling dry weight V1 (1.47 g) and V2 (1.22 g) was recorded by seeds treated with neem oil treatment after 6 months of storage periods, respectively.

The highest seedling dry weight was found in $(\mathrm{C}-128,1.27 \mathrm{~g})$ than $(\mathrm{C}-130,0.96 \mathrm{~g})$ after 3 months of storage. With packaging materials polythene bag in packed seeds V1 and V2 found significantly highest seedling dry weight after 6 months of storage.

Reference to the packaging materials the root and shoot length found to be significantly superior in polythene bags to cloth bag and jute bag. Similar results reported by Saxena $e t$ al., (1987) in onion seeds and Kumar and Rai (2006 and 2007) in maize.

\section{Vigor index - I}

The effect of seed treatments on vigour indexI was significant after 6 months of storage periods (Table 3 ).

Results revealed that significantly highest vigour index-I V1 (2267) and V2 (2229) was recorded seeds treated with neem oil treatment after 6 months of storage period, respectively. The highest vigour index-I was recorded in (C-128, 1969) than (C-130, 1928) after 6months of storage. 
Table.1 Effect of different varieties, seed treatments and packaging materials on germination per cent, root length and shoot length of chickpea seed during storage under ambient condition

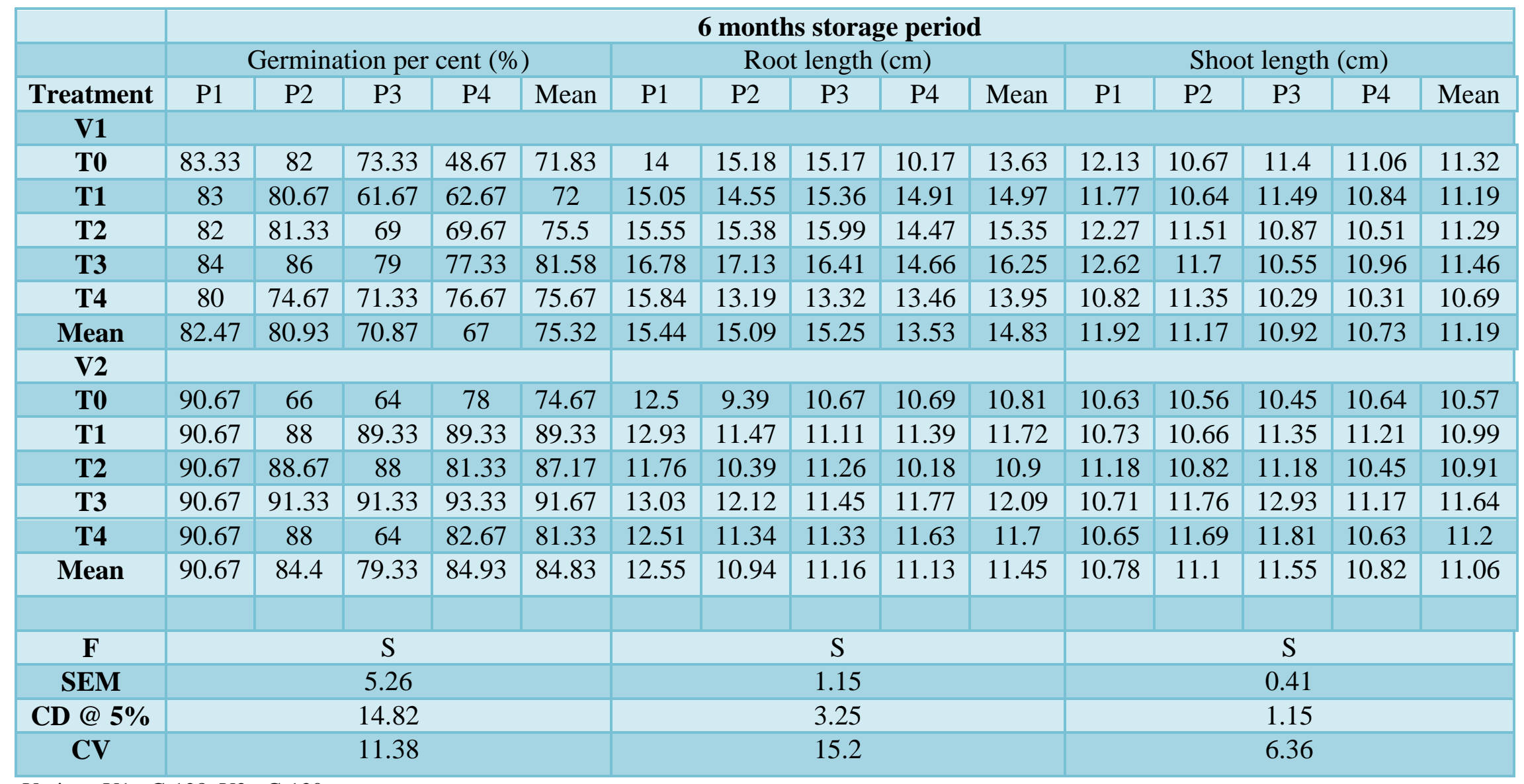

Variety: V1 $=\mathrm{C}-128, \mathrm{~V} 2=\mathrm{C}-130$

Treatment: $\mathrm{T} 1=$ Camphor oil, $\mathrm{T} 2=$ Castor oil, $\mathrm{T} 3=$ neem oil, $\mathrm{T} 4=$ Eucalyptus oil and $\mathrm{T} 0=$ Untreated seed

Packaging materials: $\mathrm{P} 1=$ Polythene bag, $\mathrm{P} 2=$ Air tight box, $\mathrm{P} 3=$ Cloth bag, $\mathrm{P} 4=$ Paper bag. 
Table.2 Effect of different varieties, seed treatments and packaging materials on seedling length, fresh weight and dry weight of chickpea seed during storage under ambient condition

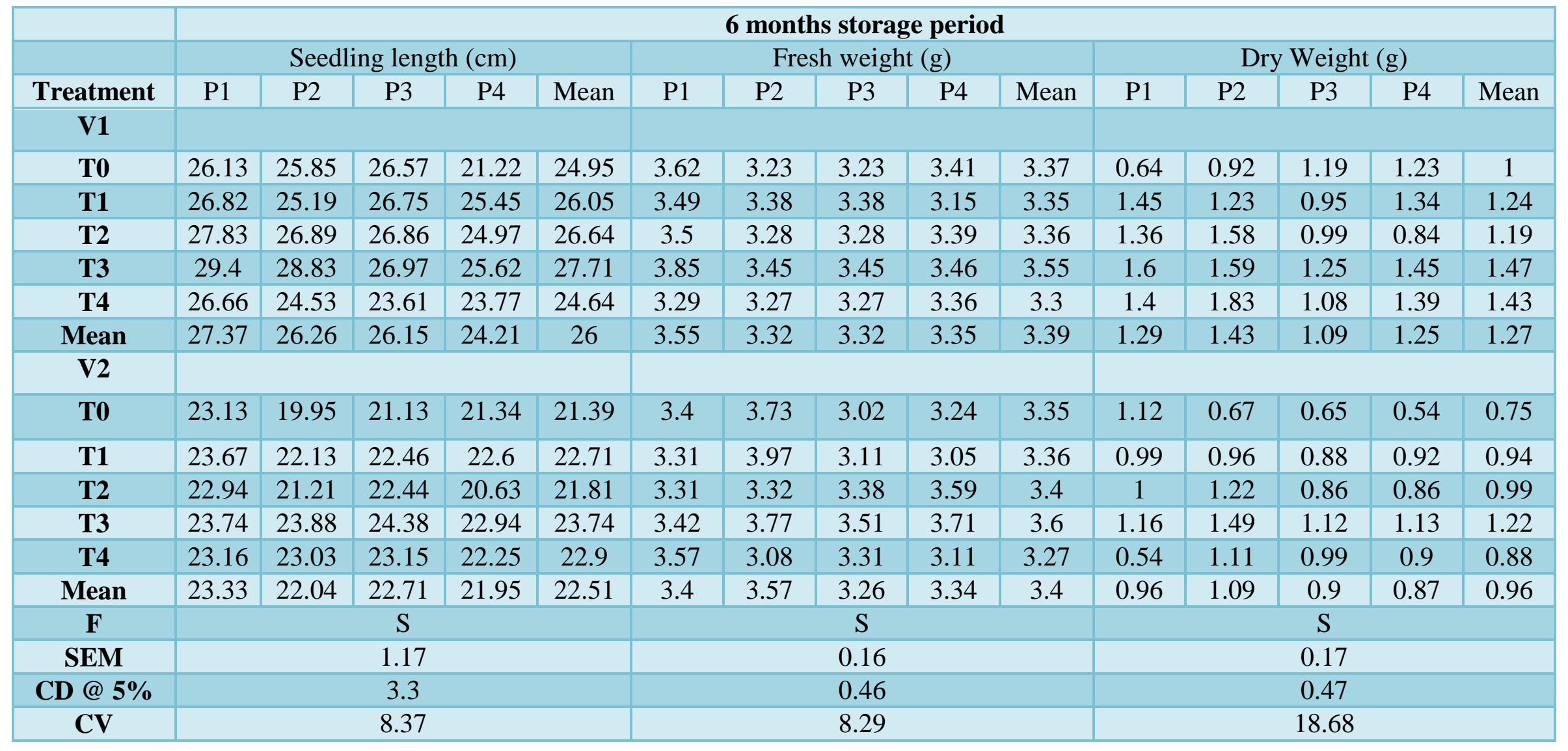

Variety: V1 $=\mathrm{C}-128, \mathrm{~V} 2=\mathrm{C}-130$

Treatment: $\mathrm{T} 1=$ Camphor oil, $\mathrm{T} 2=$ Castor oil, $\mathrm{T} 3=$ neem oil, $\mathrm{T} 4=$ Eucalyptus oil and $\mathrm{T} 0=\mathrm{Untreated}$ seed

Packaging materials: P1= Polythene bag, $\mathrm{P} 2=$ Air tight box, $\mathrm{P} 3=$ Cloth bag, $\mathrm{P} 4=$ Paper bag. 
Table.3 Effect of different varieties, seed treatments and packaging materials on vigour index-I, vigour index-II and E.C. of chickpea seed during storage under ambient condition

\begin{tabular}{|c|c|c|c|c|c|c|c|c|c|c|c|c|c|c|c|}
\hline \multicolumn{16}{|c|}{6 months storage period } \\
\hline \multirow{2}{*}{ Treatment } & \multicolumn{5}{|c|}{ Vigour index-I } & \multicolumn{5}{|c|}{ Vigour index-II } & \multicolumn{5}{|c|}{ Electrical conductivity $\left(\mathrm{dsm}^{-1}\right)$} \\
\hline & $\mathrm{P} 1$ & $\mathrm{P} 2$ & P3 & $\mathrm{P} 4$ & Mean & $\mathrm{P} 1$ & $\mathrm{P} 2$ & P3 & $\mathrm{P} 4$ & Mean & $\mathrm{P} 1$ & $\mathrm{P} 2$ & P3 & $\mathrm{P} 4$ & Mean \\
\hline \multicolumn{16}{|l|}{ V1 } \\
\hline T0 & 2173 & 2119 & 1948 & 1013 & 1813 & 53.01 & 75.23 & 87.73 & 60.88 & 69.21 & 1.44 & 1.46 & 1.56 & 1.71 & 1.54 \\
\hline T1 & 2233 & 2032 & 1651 & 1596 & 1878 & 120.8 & 99.01 & 58.65 & 84.29 & 90.69 & 1.43 & 1.4 & 1.47 & 1.88 & 1.55 \\
\hline $\mathbf{T} 2$ & 2294 & 2189 & 1861 & 1743 & 2022 & 110.42 & 127.87 & 68.23 & 58.7 & 91.3 & 1.45 & 1.43 & 1.76 & 2.05 & 1.67 \\
\hline T3 & 2466 & 2491 & 2128 & 1985 & 2267 & 134.57 & 135.43 & 98.51 & 105.38 & 118.47 & 1.33 & 1.35 & 1.37 & 1.62 & 1.42 \\
\hline T4 & 2137 & 1834 & 1687 & 1818 & 1869 & 112.97 & 116.96 & 76.58 & 99.48 & 101.5 & 1.41 & 1.43 & 1.49 & 2.14 & 1.62 \\
\hline Mean & 2261 & 2133 & 1855 & 1631 & 1970 & 106.35 & 110.9 & 77.94 & 81.75 & 94.24 & 1.41 & 1.41 & 1.53 & 1.88 & 1.56 \\
\hline \multicolumn{16}{|l|}{ V2 } \\
\hline T0 & 2102 & 1292 & 1446 & 1666 & 1627 & 102.82 & 47.81 & 39.63 & 41.65 & 57.98 & 1.27 & 2.17 & 2.92 & 1.41 & 1.94 \\
\hline T1 & 2131 & 1946 & 2005 & 2020 & 2026 & 89.43 & 83.53 & 78.89 & 81.99 & 83.46 & 1.26 & 1.26 & 1.29 & 1.27 & 1.27 \\
\hline $\mathbf{T} 2$ & 2033 & 1880 & 1971 & 1677 & 1890 & 89 & 108.09 & 76.83 & 70.09 & 86 & 1.27 & 1.22 & 1.74 & 1.36 & 1.4 \\
\hline T3 & 2368 & 2181 & 2228 & 2140 & 2229 & 107.95 & 136.09 & 101.91 & 104.52 & 112.62 & 1.25 & 1.19 & 1.27 & 1.19 & 1.23 \\
\hline T4 & 2099 & 2032 & 1516 & 1838 & 1871 & 49.09 & 95.73 & 62.55 & 74.29 & 70.42 & 1.31 & 1.67 & 3.05 & 1.35 & 1.85 \\
\hline Mean & 2147 & 1866 & 1833 & 1868 & 1929 & 87.66 & 94.25 & 71.96 & 74.51 & 82.09 & 1.27 & 1.5 & 2.05 & 1.32 & 1.54 \\
\hline $\mathbf{F}$ & \multicolumn{5}{|c|}{$\mathrm{S}$} & \multicolumn{5}{|c|}{$\mathrm{S}$} & \multicolumn{5}{|c|}{$\mathrm{S}$} \\
\hline SEM & \multicolumn{5}{|c|}{169.84} & \multicolumn{5}{|c|}{14.53} & \multicolumn{5}{|c|}{0.12} \\
\hline CD@ $@ 5 \%$ & \multicolumn{5}{|c|}{478.18} & \multicolumn{5}{|c|}{40.92} & \multicolumn{5}{|c|}{0.33} \\
\hline $\mathrm{CV}$ & \multicolumn{5}{|c|}{15.09} & \multicolumn{5}{|c|}{18.95} & \multicolumn{5}{|c|}{13.02} \\
\hline
\end{tabular}

Variety: V1 $=\mathrm{C}-128, \mathrm{~V} 2=\mathrm{C}-130$

Treatment: $\mathrm{T} 1=$ Camphor oil, $\mathrm{T} 2=$ Castor oil, $\mathrm{T} 3=$ neem oil, $\mathrm{T} 4=$ Eucalyptus oil and $\mathrm{T} 0=$ Untreated seed

Packaging materials: P1= Polythene bag, $\mathrm{P} 2=$ Air tight box, $\mathrm{P} 3=$ Cloth bag, $\mathrm{P} 4=$ Paper bag. 
With packaging materials polythene bag in packed seeds found significantly highest vigour index-I V1 and V2 after 6 months of storage.

\section{Vigor index -II}

The effect of seed treatments on vigour indexII was significant after 6 months of storage periods (Table 3). Results revealed that significantly highest vigour index-II V1 (118.47) and V2 (112.62) was recorded seeds treated with neem oil treatment after 6 months of storage periods, respectively. The highest vigour index-II was recorded in $(\mathrm{C}-128$, 94.24) than (C-130, 82.09) after 6 months of storage. With packaging materials polythene bag in packed seeds found significantly highest vigour index-II V1 and V2 after 6 months of storage.

High relative humidity and temperature prevailing during the storage period. Improper storage may result destruction of vigour or even complete loss of viability (Hossain, 1978).

A significantly higher seed quality parameters in the seeds stored in polythene bag may be due to higher test weight of seeds with constant seed moisture maintenance. Such results are reported by Tammanagouda (2002), Arati (2000) and Dwivedi and Shukla (1990) in pulses.

\section{Electrical Conductivity $\left(\mathrm{dsm}^{-1}\right)$}

The effect of seed treatments on electrical conductivity $\left(\mathrm{dsm}^{-1}\right)$ was significant after 6 months of storage periods (Table 3 ). Results revealed that significantly $\mathrm{E}$. C. lowest value $\mathrm{V} 1\left(1.42 \mathrm{dsm}^{-1}\right)$ and V2 $\left(1.23 \mathrm{dsm}^{-2}\right)$ was recorded by seeds treated with neem oil treatment after 6 months of storage periods, respectively. The E.C. lowest value was recorded in $\left(\mathrm{C}-130,1.54 \mathrm{dsm}^{-1}\right)$ than $(\mathrm{C}-128$, $1.56 \mathrm{dsm}-1)$ after 6 months of storage. With packaging materials polythene bag in packed seeds found significantly lowest E. C. after 3 months of storage.

Changes in seed which include membrane degradation, accumulation of toxic metabolites, decreased enzymatic activity, lipid auto-oxidation, failure of repair mechanisms and genetic degradation. Consequences of these factors led to reduced viability / germinability and vigour in stored seeds.

It is concluded that from the present investigation in chickpea of all treated seeds, seeds treated with neem oil recorded significantly higher seed quality parameters where as high effect of as observed when seed were treated with $\mathrm{T}_{3}$ and stored under $\mathrm{P} 1$ packaging materials. Variety $\mathrm{C}-128$ showed high seed and more in seed quality characters during storage. It can be collected that if seeds are treated with $\mathrm{T}_{3}$ and packed in polythene bag help in maintain the quality storability of chickpea seeds.

\section{Acknowledgement}

Author is thankful to Advisor Dr. Abhinav Dayal, Co-Advisor Dr. A. K. Chaurasia and advisory committee for continuous support, guidance, co -operation. Author feels immense pleasure to thank all the advisory committee members for their constructive criticism and especially head of Post Graduate studies Prof (Dr.) Suresh B. G. Department of Genetics and Plant Breeding, SHUATS, Allahabad, Uttar Pradesh (U.P), India for providing necessary facilities.

\section{References}

Annual Report DPD (2016-2017). Source DES 2016-2017-IIIrd Advance Estimate.

AOSA 2002. Seed vigour testing handbook. Association of official seed analysis. 
Arati, P., (2000). Influence of containers and seed treatments on storability of chickpea. M. Sc. (Agri.) Thesis, Univ. Agric. Sci., Dharwad.

Doijode, S. D. (1988). Comprising of storage containers for storage of French been seeds.

Fisher, R.A (1950). Handbook of Agriculture Statistics. Achal Prakashan Mandir Kanpur. 332-334.

Hossain, S.M.A. (1978) Storage environment of seeds. In: Lecture on Seed Production and Certification. (Hossain, S. M. A. and M. A Hossain ed.) GTI, Bangladesh Agic. Univ. Mymensingh. pp. 87-92.

International Seed Testing Association (ISTA) 1985. International rules for seed testing. Seed Science and Technology, 13: 299-355.

Kaushik, R.M. Ugale, S. D. and Patil, R. B. (1987). Effect of seed size on germination, seedling vigour and test weight of pearl millet. Seed Research.15(2):210-213.
Maesen, V. D. and Pundir, R. P. S. (1984). Availability and use of wild Cicer germplasm. Plant Genetic Resources Newsletter, 57: 19-24.

P. N. Bahl\& P. M. Salimath. viii 313 pp. Lebanon, USA: Science Publishers Inc. (1996). The Journal of Agricultural Science, 129(3):367-369.

Prashant Kumar Rai, Girjesh Kumar and K.K. Singh (2011) Influence of packaging material and storage time on seed germination and chromosome biology of inbred line of maize (Zea mays L.). Journal of Agricultural Technology, 7(6): 1765-1774.

Singh, G. and Singh, H. (2007). Maintenance of germinability of soybean (Glycine max L.) seeds. Seed Research,20:4950.

Tammangouda, P., (2002) influence of organics on seed yield, quality and storability studies in green gram $\mathrm{Cv}$. Chinamung M.Sc. (Agri) Thesis Univ. Agric. Sci., Dharwad (India).

\section{How to cite this article:}

Jagnnath Gupta, Abhinav Dayal, A.K. Chaurasia, Vishal Kumar and Nawaz Ali. 2018. Effect of Different Packaging Materials and Pre-Storage Treatments on Storability of Chickpea (Cicer arietinum L.) Seeds. Int.J.Curr.Microbiol.App.Sci. 7(08): 1983-1990. doi: https://doi.org/10.20546/ijcmas.2018.708.228 